African J. Biol. Sci., 16 (1): 233-244 (2020)

ISSN 1687-4870

www.ajbs.journals.ekb.eg

e- ISSN 2314-5501 (online)

E.mail: aasdjournal@yahoo.com

\title{
Potential protective role of Melilotus officinalis extract against Cisplatin -induced cardiac and pulmonary toxicities in rats
}

\author{
Safaa M. Faid \\ Department of Home Economics, Faculty of Specific Education, Ain Shams University, \\ Cairo, Egypt \\ E mail: safaafaid73@gmail.com
}

Received:November 3, 2020; Accepted: November 30, 2020 ; Available onlineDecember 20, 2020

\begin{abstract}
Cisplatin (Cis) is a chemotherapeutic drug that is currently used to treat a variety of cancers.However, intrinsic cardiac and pulmonary toxicities, as well as other adverse effects, limit its practical application. Because Melilotus officinalis (MO) extract contains antioxidant and anti-inflammatory capabilities, the current study was conducted to investigate its protective effect on the heart and lung damage induced from administration of Cisplatin. Thirty rats were randomly divided into six groups (A,B,C,D,E,F) of 5 rats each; Group A was used as negative control and received only water; Group B was intraperitoneally (i.p) injected $5 \mathrm{mg} / \mathrm{kg}$ of Cis once every 2 days for a total of 8 days (+ve Control); Groups C and D were given 100 and $200 \mathrm{mg}$ of MO via oral administration, respectively, for 7 weeks and then exposed to i.p administration of $5 \mathrm{mg} / \mathrm{kg}$ b.wt cisplatin on the $7^{\text {st }}$ week; Groups E and F received $5 \mathrm{mg} / \mathrm{kg}$ b.wt of cisplatin intraperitoneally and then orally received 100 and $200 \mathrm{mg}$ of $\mathrm{MO}$ for 7 weeks. The results indicated that cisplatin administration by rats of group B resulted in elevated levels of their LDH, CK, MDA, and TNF-and significant decreases in SOD levels in the heart tissues, as well as a significant decrease in lung GSH and Caspase-3 activity compared with control group (A). In groups C and D rats, pretreated with MO extract showed improvement in their investigated biochemical parameters. MO also showed improvements in histological structures of heart and lung damadge in rats of groups (C \& D). Groups (F \& D) showed no significant change in the examined biochemical parameters as well as histotlogical structure of damage heart and lungs compared with the positive control group (B). The present findings suggested that MO extract has a protective effect against cisplatin-induced cardiac and pulmonary damage.
\end{abstract}

Keywords: Cisplatin, Melilotus officinalis, cardiac damage, pulmonary damage.

INTRODUCTION

Cisplatin (Cis) is a commonly used in chemotherapy to treat ovarian, lung, head and neck, testicular, and bladder malignancies (Hassen et al.,2021).When the dosage of Cis is increased, the drug's therapeutic efficacy improves, but the danger of different side effects rises as well. Oxidative stress, which affects the lungs and other tissues and organs, is one of its side effects (Chen et al.,2007). Interstitial inflammation, fibrosis, structural lung damage, and cardiovascular problems have all been observed during cisplatin chemotherapy. Several investigations have found that Cis-induced cardiotoxicity is characterised by electrocardiographic abnormalities, arrhythmia, cardiomyopathy, and congestive heart failure, among other things. Increased lipid peroxidation caused by reactive oxygen species (ROS) and a loss in antioxidant state have been blamed for the deleterious consequences of cisplatin-induced pulmonary and cardiovascular damage (Pratibha et al., 2006). Previous studies found that cisplatin increased the quantity of 


\section{Safaa M. Faid}

malondialdehyde (MDA) in animal lungs, resulting in a decrease in tissue antioxidant capacity. This entails the activation of caspases and subsequent apoptosis, as well as the onset of necrosis owing to apoptotic abortion (Ali et al., 2006) Oxidative DNA damage in the lung tissue of a cisplatintreated group of rats with increasing in their total oxidant levels were observed by Geyikoglu et al. (2017).

Plant-derived compounds have received a lot of attention recently because their phenolic compounds have a lot of free radical scavenging (antioxidant) activity, which is limited by their reactivity as hydrogen or electron-donating agents, the stability of the resulting antioxidant derived radical, their reactivity with other antioxidants, and their metal chelating properties (El-Motelp et al., 2021).

Melilotus officinalis (MO), often known as yellow sweet clover or honey lotus, is a fragrant annual or biennial herb in the Leguminosae (Fabaceae) family (Paun et al., 2020). This plant has a wide range of pharmacological actions, and all of its parts are used to treat various ailments (Anwar et al., 2008). Inflammation, edoema, foot ulcers, and headaches are all treated with this plant (Plesca-Manea et al., 2002). M. officinalis contained coumarins, melilotin, phenolic acids, flavonoids, steroids, saponins, volatile oils, fats, triterpenes, carbohydrates, sugar, anthraquinone glycosides, mucilage, tannin, bis hydroxycoumarin, choline, alcohols, uric acid, and a variety of other chemical groups, according to the phytochemical analysis. Antimicrobial, antioxidant, anticancer, anti-inflammatory, neural, protective, sedative, anxiolytic, smooth muscle relaxant, hypotensive, and a variety of other pharmacological properties (AlSnafi, 2020). In addition, $M$. officinalis has been stated to be a hypotensive, antifungal (Braga et al., 2013; Nasser et al., 2014;Anwer et al.,2015), and analgesic agent (Heidari et al.,2001).
The goal of this study was to evaluate the protective effect of Melilotus officinalis extract against cisplatin-induced oxidative pulmonary and cardiac damage in rats using biochemical and histological analysis.

\section{MATERIALS AND METHODS Chemicals and drugs}

Cisplatin (Cis) (Sigma-Aldrich, St. Louis, MO, USA) was dissolved in phosphate buffered saline (PBS) and the dose of $5-\mathrm{mg} / \mathrm{kg}$ cisplatin was injected intraperitoneally (i.p.) once in every 2 days for a total of 8 days according toTopal et al. (2018).

\section{Plant preparation and extraction procedures}

The Experimental Station of Medical Plants (ESMP), Faculty of Pharmacy, Cairo University, provided the Melilotus officinalis(MO) plant.The dried plant was chopped into small pieces and powdered coarsely. Pieces of plants were defatted by keeping it with petroleum ether for the duration of $72 \mathrm{~h}$ and thereafter powder was dried. Aqueous extract of this defatted powder was gained by the process of maceration and became $12.5 \% \mathrm{w} / \mathrm{w}$ of percentage yield.

\section{Animals care}

Thirty male albino rats (60 daysold, weighing 130:150g) were gained from the animal house of the National Research Center, Cairo, Egypt, and fed on a basal diet for eight days. The basal diet consisted of corn starch $70 \%$, casein $10 \%$ corn oil $10 \%$, salt mixture $4 \%$, vitamin mixture $1 \%$ and cellulose $5 \%$ according to AOAC (2005). Rats were kept in a well-ventilated room and exposed to natural light on a daily basis (12:12 h light-dark cycle).The mice were kept in metabolic cages under typical laboratory conditions (temperatures of $25 \pm 2{ }^{\circ} \mathrm{C}$ ). They were allowed free access to standard dry pellet diet and water ad libitum. They were acclimatized for 1week pre-experimentation period. 


\section{Potential protective role of Melilotus officinalis extract against Cisplatin -induced cardiac and pulmonary toxicities in rats}

\section{Experimental groups}

These include 30 male albino rats that were divided randomly into 6 groups as follows:

Group A. negative Control: rats orally received water $(5 \mathrm{ml} / \mathrm{kg}$ b.wt $)$ for 21 days.

Group B. positive Control : rats were given intraperitoneally $5-\mathrm{mg} / \mathrm{kg} \quad$ b.wt Cisplatin (Cis) once in every 2 days for a total of 8 days according to Topal et al.(2018).

Group C. : rats received $100 \mathrm{mg} / \mathrm{kg}$ b.wt of MO extract for the duration of three days and then administered $5-\mathrm{mg} / \mathrm{kg}$ cisplatin intraperitoneally on the $7^{\text {th }}$ week.

Group D. : rats received $200 \mathrm{mg} / \mathrm{kg}$ b.wt of MO extract for the duration of three days and then administered $5-\mathrm{mg} / \mathrm{kg}$ cisplatin intraperitoneally on the $7^{\text {th }}$ week.

Group E. rats received $5 \mathrm{mg} / \mathrm{kg}$ b.wt of cisplatin intraperitoneally and then received $100 \mathrm{mg} / \mathrm{kg} \mathrm{b}$.wt of $\mathrm{MO}$ extract for 7 weeks orally.

Group F. rats received $5 \mathrm{mg} / \mathrm{kg}$ b.wt of cisplatin intraperitoneally and then received $200 \mathrm{mg} \mathrm{kg} / \mathrm{b}$.wt of MO extractfor 7 weeks orally.

\section{Body weight (BW) gain:}

Body weight (BW) gain were calculated at the end of experimental period as reported by Chapman et al. (1959).

\section{Sample collection}

Rats were sacrificed under anaesthesia at the end of the experiment. Hearts and lungs were removed, dressed and washed in ice-cold phosphate buffered saline ( $\mathrm{pH}$ 7.4). One half of each heart and lung tissue was taken and fixed in $10 \%$ formalin solution for histopathological examination.The remaining half of each heart and lung was homogenised right away for biochemical testing.

Homogenized cardiac tissue
samples were
malondialdehyde (MDA) levels by the method of Ohkawa et al. (1977), superoxide dismutase (SOD) and lactate dehydrogenase (LDH) enzyme activities were resolute using the antioxidant enzyme assay kit method (Abcam) which was based on the method of Pandurangan et al. (2015). Creatine Kinase(CK) was measured using Colorimetric Assay Kit (ab155901) according to McRae et al. (2020). The amount of tumour necrosis factor (TNF-) was evaluated using an ELISA methodology and a TNF-test kit acquired from Assay Pro.,Co., USA according to the method describedby Taylor (2001). TNF- a levels were measured using astandard quantitative sandwich ELISA.

\section{Biochemical analysis of pulmonary tissue}

Homogenized pulmonary tissue samples were analyzed formalondialdehyde (MDA) levels by the method of Ohkawa et al. (1977), The glutathione Assay Kit was used to determine the level of glutathione (GSH) (Abcam). This was based on the spectrophotometric method of Pandurangan et al. (2015). The amounts of caspase-3 were determined using an ELISA kit (ab181418) obtained from Abcam, UK. The assay ranged from 0.156 to $10 \mathrm{ng} / \mathrm{ml}$, and the results were represented in terms of $\mathrm{ng} / \mathrm{mg}$ of tissue proteins according to Jiang et al.(2020).

\section{Histopathological examination}

Samples of rats' heart and lung were fixed in a $10 \%$ formalin solution for 24 hours. The paraffin blocks were cut into 6-um thick sections and were stained with hematoxylin and eosin after regular tissue processing. All sections were examined under a light microscope.

\section{Statistical analysis}

One-way analysis of variance, followed by Tukey's post hoc test for multiple comparison were used. The results were expressed as group mean standard error of mean, while the level of significance was $\mathrm{P}<0.05$. 


\section{Safaa M. Faid}

\section{RESULTS AND DISCUSSION Body weight:}

It was clear from data in Table (1) that the average body weights gain of +ve cis group (B) recorded a very highly significant decrease $(\mathrm{p}<0.001)$ as compared to the -ve control group (A). At the same time the average body weights gain of cis rats treated with either $\mathrm{MO}(\mathrm{LD})+\mathrm{CIS}$ or $\mathrm{MO}(\mathrm{HD})+\mathrm{CIS}$ revealed a highly significant increase $(\mathrm{p}<0.01)$ as compared to cis group (B). Moreover, data showed a very highly significant increase in the body weight gain of cis group treated with both CIS+MO(LD) and CIS+MO (HD) in relation to cis group. The present study revealed a significant decrease in body weight of male albino rats given cisplatin. Similar observation was recrded by Hassen et al., (2021) who used cisplatin intraperitoneal in rats and observed a decrease in their body weights.

Table 1: Effect of cisplatin and different treatments of Melilotus officinalis (MO) on body weight.

\begin{tabular}{|c|c|c|c|c|c|c|}
\hline Groups & $\begin{array}{c}\text { +Ve Control } \\
\text { B }\end{array}$ & $\begin{array}{c}\text {-Ve Control } \\
\text { A }\end{array}$ & $\begin{array}{c}\text { MO } \\
\text { (LD)+CIS } \\
\text { C }\end{array}$ & $\begin{array}{c}\text { MO(HD)+ } \\
\text { CIS } \\
\text { D }\end{array}$ & $\begin{array}{c}\text { CIS+MO (LD) } \\
\text { E }\end{array}$ & $\begin{array}{c}\text { CIS+MO (HD) } \\
\text { F }\end{array}$ \\
\hline $\begin{array}{c}\text { Body weight gain } \\
\text { (g) }\end{array}$ & $\begin{array}{c}244.84 \pm \\
8.80\end{array}$ & $\begin{array}{c}130.79 \pm \\
8.42 *\end{array}$ & $\begin{array}{c}206.69 \pm \\
6.1 *\end{array}$ & $\begin{array}{c}215.01 \pm \\
18.5 *\end{array}$ & $\begin{array}{c}167.87 \pm \\
18.6 * \#\end{array}$ & $\begin{array}{c}182.65 \pm \\
19.55^{*} \# \$\end{array}$ \\
\hline
\end{tabular}

(LD: low dose, HD: hight dose)

Values are presented as mean \pm SEM

*: statistically significant compared to corresponding value in - ve control group $(\mathrm{P}<0.05)$

\#: statistically significant compared to corresponding value in +ve control or cis group $(\mathrm{P}<0.05)$

$\$$ : statistically significant compared to corresponding value in $(\mathrm{C}, \mathrm{D})$ group $(\mathrm{P}<0.05)$

\section{2-Effect of Melilotus officinalis (MO) extract on cardiac parameters in rats treated with cisplatin:}

The results of MO pretreatment against cisplatin-induced impairment of cardiac enzymes, antioxidant systems, and lipid peroxidation in heart tissue are shown in Tables $(2 \& 3)$. There was a significant $(\mathrm{P}<0.001)$ decrease in the heart SOD with a significant increase in MDA, $\mathrm{LDH}, \mathrm{CK}$, TNF- $\alpha$ and IL-6 levels in the +ve group (B) compared with -ve control rats (Group A). MO pre-treatment Groups C and D showed significantly $(\mathrm{P}<0.01)$ ecrease in levels of SOD, MDA, LDH, CK, and TNF- $\alpha$ when compared to positive control group (B). The levels of all previous cardiac parameters in the MO treated Groups E and F rats were not significantly $(\mathrm{P}>0.05)$ different from the positive control group (B).

Chemotherapeutic drugs can break cell membranes, allowing intracellular proteins like lactate dehydrogenase (LDH) and creatine kinase to leak out (CK). These are biomarkers that are used to diagnose and assess the existence and severity of cardiac injury. In a rat model of cardiac damage caused by cisplatin, El-Awady et al. (2011) reported significant increases in the activities of serum LDH and CK, following a single dose of cisplatin compared to a control group. Cisplatininduced cardiac toxicity can result in myocardial injury, as demonstrated by elevations in cardiac biomarker levels (Dugbartey et al. 2016). In the present study the positive group (B) showed a large increase in cardiac MDA concentration, which was accompanied by a large depletion in cardiac SOD.This result is consistent with those of El-Awady et al. (2011) and Dugbartey et al. (2016) who testified that oxidative stress is caused by a mismatch between the production of reactive oxygen species (ROS) and the biological system's ability to quickly reverse the effects of pro-oxidants. Any 


\section{Potential protective role of Melilotus officinalis extract against Cisplatin -induced cardiac and pulmonary toxicities in rats}

shift in the normal redox state of a cell causes oxidative stress, which can be detrimental to cells. Cisplatin has the ability to shift the redox balance in cells by conjugation, resulting in the depletion of the antioxidant glutathione as well as impairment of mitochondrial respiration, resulting in the generation of reactive oxygen species (ROS) (Nita et al., 2016). During cisplatin-based chemotherapy in cancer patients, several authors have seen significant reductions in plasma concentrations and activity of different antioxidants, including glutathione (Nakhaee et al., 2010). Excessive ROS generation causes lipid peroxidation, which represents oxidative stress and has been linked to cisplatin-induced heart damage (Dugbartey et al.,2016). Oxidative stress is the main mechanism underlying cisplatin-induced cardiac toxicity (ElAwady et al., 2011). Rosic et al. (2016) have exposed that in In the isolated heart of rats given cisplatin, there was a decrease in coronary flow and an increase in cardiac enzyme leakage, as well as elevated ROS levels and lipid peroxidation.In addition, El-Awady et al. (2011) showed that SOD levels were reduced in cardiac tissue of cisplatin treated rats. Cytokines make important roles in normal cell physiology. Inflammation, immunological response, and tissue damage are all associated to or heal these conditions. Increasing data suggests that cisplatin causes a slew of inflammatory cytokines and chemokines to be released, including nuclear factor kappa B (NF-B) translocation from the cytosol to the nucleus, which leads to production of tumor necrosis factor alpha (TNF- $\alpha)$ in cardiomyocytes, a pro-inflammatory cytokines that is actively involved in cisplatin-induced inflammation (ElSawalhi, 2013). Chowdhury et al., 2016).

In the current study graded dosages of MO pre-treatment provided dosedependent protection against cisplatin toxicity as shown in levels of antioxidant, oxidative markers, and cardiac enzymes. (Table 2) and inflammatory cytokines (Table 3). According to this work, it was create that MO has anti-oxidant and antiinflammatory properties and there are phenolic and flavonoids in this plant, but considering that antioxidant effect of $\mathrm{MO}$ may due to the higher levels of flavonoids in the M. officinalis that have more antiinflammatory properties (Khosroyar and Arastehnodeh, 2018).

Table 2: Effect of cisplatin and different treatments of MO on antioxidant, oxidative markers, and cardiac enzymes.

\begin{tabular}{|c|c|c|c|c|c|c|}
\hline $\begin{array}{l}\text { groups } \\
\text { parameters }\end{array}$ & $\begin{array}{c}\text {-Ve Control } \\
\text { A }\end{array}$ & $\begin{array}{c}+ \text { Ve Control } \\
\text { B }\end{array}$ & $\begin{array}{c}\text { MO(LD)+CIS } \\
\text { C }\end{array}$ & $\begin{array}{c}\text { MO(HD)+CIS } \\
\text { D }\end{array}$ & $\begin{array}{c}\text { CIS+MO (LD) } \\
\text { E }\end{array}$ & $\begin{array}{c}\text { CIS+MO (HD) } \\
\text { F }\end{array}$ \\
\hline $\begin{array}{l}\text { MDA (nmol/mg } \\
\text { protein) }\end{array}$ & $\begin{array}{c}2.45 \pm \\
0.02\end{array}$ & $\begin{array}{l}8.24 \pm \\
0.002 *\end{array}$ & $\begin{array}{l}4.15 \pm \\
0.001 *\end{array}$ & $\begin{array}{l}3.71 \pm \\
0.06 *\end{array}$ & $\begin{array}{c}7.64 \pm \\
0.001 * \#\end{array}$ & $\begin{array}{c}6.45 \pm \\
0.01 * \# \$\end{array}$ \\
\hline $\begin{array}{c}\text { GSH(nmol/mg } \\
\text { protein) }\end{array}$ & $\begin{array}{c}0.45 \pm \\
0.01 \\
\end{array}$ & $\begin{array}{c}0.18 \pm \\
0.001 *\end{array}$ & $\begin{array}{l}0.40 \pm \\
0.06 * \\
\end{array}$ & $\begin{array}{c}0.39 \\
0 \pm .02 * \\
\end{array}$ & $\begin{array}{c}.31 \pm \\
\mathbf{0 . 0 1} * \# 0\end{array}$ & $\begin{array}{c}0.24 \pm \\
0.001 * \# \$ \\
\end{array}$ \\
\hline $\begin{array}{c}\text { SOD } \\
\text { ( nmol/mg protein) }\end{array}$ & $\begin{array}{c}55.15 \pm \\
0.05 \\
\end{array}$ & $\begin{array}{l}\text { 12.1士 } \\
0.07 * \\
\end{array}$ & $\begin{array}{c}45.25 \pm \\
0.05 * \\
\end{array}$ & $\begin{array}{c}47.15 \pm \\
0.05 * \\
\end{array}$ & $\begin{array}{l}\text { 31.14士 } \\
0.05 * \#\end{array}$ & $\begin{array}{c}27.68 \pm \\
0.005 * \# \$ \\
\end{array}$ \\
\hline CK-MB(U/L) & $\begin{array}{c}151.41 \pm \\
0.02 \\
\end{array}$ & $\begin{array}{c}354.54 \pm \\
0.06 * \\
\end{array}$ & $\begin{array}{c}201.25 \pm \\
0.001 * \\
\end{array}$ & $\begin{array}{c}193.21 \pm \\
0.02 * \\
\end{array}$ & $\begin{array}{l}250.14 \pm \\
0.001 * \# \\
\end{array}$ & $\begin{array}{c}283.01 \pm \\
0.001 * \# \$ \\
\end{array}$ \\
\hline LDH (U/L) & $101.5 \pm .01$ & $199.51 \pm .02 *$ & $120.40 \pm .05^{*}$ & $115.61 \pm .02 *$ & $175.65 \pm .01 * \#$ & $150.65 \pm .005 * \# \$$ \\
\hline
\end{tabular}

(LD: low dose, HD: hight dose) Values are presented as mean \pm SEM

*: statistically significant compared to corresponding value in -ve control group $(\mathrm{P}<0.05)$

\#: statistically significant compared to corresponding value in $+v e$ control or cis group $(\mathrm{P}<0.05)$

$\$$ : statistically significant compared to corresponding value in $(\mathrm{C}, \mathrm{D})$ group $(\mathrm{P}<0.05)$ 


\section{Safaa M. Faid}

Table 3: Effect of cisplatin and different treatments of MO on inflammatory cytokines.

\begin{tabular}{|c|c|c|c|c|c|c|}
\hline parameters & $\begin{array}{c}\text {-Ve Control } \\
\text { A }\end{array}$ & $\begin{array}{c}+ \text { Ve Control } \\
\text { B }\end{array}$ & $\begin{array}{c}\text { MO(LD) } \\
+ \text { CIS } \\
\quad \mathrm{C}\end{array}$ & $\begin{array}{l}\text { MO(HD)+ } \\
\text { CIS } \\
\text { D }\end{array}$ & $\begin{array}{c}\text { CIS+MO } \\
\text { (LD) } \\
\text { E }\end{array}$ & $\begin{array}{c}\text { CIS+MO } \\
\text { (HD) } \\
\text { F }\end{array}$ \\
\hline $\begin{array}{c}\text { TNF- alpha } \\
\text { (pg/mg) }\end{array}$ & $\begin{array}{c}131.52 \pm \\
0.01\end{array}$ & $\begin{array}{c}\text { 306.25 } \\
0.002 *\end{array}$ & $\begin{array}{l}150.14 \pm \\
0.002 *\end{array}$ & $\begin{array}{l}\text { 141.54士 } \\
0.04 *\end{array}$ & $\begin{array}{l}241.25 \pm \\
0.005 * \#\end{array}$ & $\begin{array}{l}214.08 \pm \\
0.02 * \# \$\end{array}$ \\
\hline
\end{tabular}

(LD: low dose, HD: hight dose)

Values are presented as mean \pm SEM

*: statistically significant compared to corresponding value in - ve control group $(\mathrm{P}<0.05)$

\#: statistically significant compared to corresponding value in $+v e$ control or cis group $(\mathrm{P}<$ $0.05)$

$\$$ : statistically significant compared to corresponding value in $(\mathrm{C}, \mathrm{D})$ group $(\mathrm{P}<0.05)$

\section{3- Effect of Melilotus officinalis (MO) extract on lung parameters in rats treated with cisplatin:}

The results of Caspase-3, MDA, and GSH in the control and other studied groups are illustrated in Table (4). It was obvious that Cis administration increased MDA level and caspase-3 activity but, significantly decreased the content of GSH. MDA, GSH levels, and caspase-3 activity were ameliorated significantly after MO pretreatment at doses of 100 and $200 \mathrm{mg} \mathrm{kg} / \mathrm{b}$.wt in groups (C and D) rats, compared to the the +ve control group (B), however, the level of Caspase-3, MDA, and GSH did not return to normalized control values in groups ( $\mathrm{E}$ and $\mathrm{F}$ ) rats did not receive pretreatment with graded doses of MO.

Caspase- 3 belongs to the group of intrinsic protein factors that play a role in programmed cell death (apoptosis). Caspases-3 inactivation reduces apoptosis in a variety of situations, including activation-induced cell death (AICD). It is an essential component in apoptotic events that are remarkably system- and stimulusdependent (Woo et al.,1998). As a result, it's not surprising that active caspase-3 lung tissue concentrations are much higher in the Cis group, given that the same group's lipid peroxidation products (MDA levels) are also much higher.Earlier studies found that the activation of the caspase system is nearly proportional to the degree of lipid peroxidation (Ayala et al.,2014; Eken et al.,2019).The therapeutic use of cisplatin induces oxidative stress and DNA obliteration in noncancerous tissues (e.g. kidney, liver, testicular, brain, and lung) (Chen et al.,2007). Tissue damage may be linked to a decline in antioxidant defence systems in the pathogenesis of cisplatin-induced oxidative damage (Pratibha et al.,2006). In the present work, lung tissue levels of MDA and GSH, and endogenous antioxidant molecule were significantly decreased in the +ve Cis group as compared with those in the ve control group. Afsar et al. (2018) stated that MDA levels elevated in the presence of cisplatin-induced lung destruction, whereas the levels of GSH and other enzymatic antioxidants were reduced significantly(Adejuwon et al.,2015; Univar et al.,2019).

Pretreatment with MO extract in groups $\mathrm{C}$ and $\mathrm{D}$ rats remarkably ameliorated the disrupted antioxidant defense systems in a dose-dependent manner by improving the profiles of cisplatin-depleted antioxidant enzymes (SOD) and intracellular GSH and the level of MDA generated in the lung and heart tissues. These detected ameliorations are suggested to be connected to the phytoantioxidants components particularly flavonoids in of the MO. These findings 


\section{Potential protective role of Melilotus officinalis extract against Cisplatin -induced cardiac and pulmonary toxicities in rats}

are consistent with previous research on improving MO's free radical scavenging capacity in the treatment of cisplatin- induced damage as recognized by Al-Snafi (2020).

Table 4: Effect of cisplatin and different treatments of MO extract on antioxidant, oxidative markers, and apoptic marker.

\begin{tabular}{|c|c|c|c|c|c|c|}
\hline groups & $\begin{array}{c}- \text {-Ve Control } \\
\text { A }\end{array}$ & $\begin{array}{c}+ \text { Ve Control } \\
\text { B }\end{array}$ & $\begin{array}{c}\text { MO(LD)+C } \\
\text { IS } \\
\text { C }\end{array}$ & $\begin{array}{c}\text { MO(HD)+CIS } \\
\text { D }\end{array}$ & $\begin{array}{c}\text { CIS+MO (LD) } \\
\text { E }\end{array}$ & $\begin{array}{c}\text { CIS+MO (HD) } \\
\text { F }\end{array}$ \\
\hline $\begin{array}{c}\text { MDA } \\
\text { (nmol/mg } \\
\text { protein) }\end{array}$ & $4.25 \pm .02$ & $9.41 \pm .002 *$ & $6.25 \pm .002 *$ & $6.01 \pm .05^{*}$ & $8.65 \pm .005 * \#$ & $7.15 \pm .02 * \# \$$ \\
\hline $\begin{array}{l}\text { GSH(nmol/ } \\
\text { mg protein) }\end{array}$ & $0.68 \pm .02$ & $0.26 \pm . .005^{*}$ & $0.52 \pm .06 *$ & $0.58 \pm .01 *$ & $0.36 \pm .01 \#$ & $0.41 \pm .005 * \#$ \\
\hline $\begin{array}{c}\text { Caspase } 3 \\
\text { (pg/mg) }\end{array}$ & $3.41 \pm .05$ & $22.54 \pm .07 *$ & $10.24 \pm .03 *$ & $9.54 \pm .01 *$ & $19.36 \pm .01 * \#$ & $15.01 \pm .02 * \# \$$ \\
\hline
\end{tabular}

LD: low dose, HD: hight dose)

Values are presented as mean \pm SEM

*: statistically significant compared to corresponding value in -ve control group $(\mathrm{P}<0.05)$

\#: statistically significant compared to corresponding value in +ve control or cis group $(\mathrm{P}<0.05)$

$\$$ : statistically significant compared to corresponding value in $(\mathrm{C}, \mathrm{D})$ group $(\mathrm{P}<0.05)$

\section{Histopathological examination}

\section{1- Heart Tissue:}

Light microscope showed normal cardiac muscle fibers in longitudinal section (Fig. -A) with prominent striations and centrally located nuclei and with cardiac wall showing normal pericardium. Each muscle fiber was surrounded by an endomysium of delicate connective tissue with a rich capillary network. Fibroblast nuclei tend to be more flattened and darker staining than those of cardiac muscle cells and were peripherally located. Many normal capillaries were seen among the cardiac muscle fibers. However, kidney tissues of rats treated with cisplatin showed induced damage where the wall of pericardium was detached and the myocardial blood vessels were mildly congested (Fig. 1B). Tissue damage may be linked to a decline in antioxidant defence systems in the pathogenesis of cisplatin - induced oxidative damage
(Pratibha et al., 2006).

Examinations of sections kidney of rats from groups $(\mathrm{C} \& \mathrm{D})$ taken $\mathrm{MO}$ extracts with different doses showing viable cardiac muscle fibers with distinct cell borders and central ovallelongated nuclei, and average myocardial blood vessel (Fig. $1 \mathrm{C} \& \mathrm{D}$ ). This indicated that there was an improvement in the kidney tissue which related to the usage of MO extract since these detected ameliorations are suggested to be connected to the phytoantioxidants components particularly flavonoids in the MO extract, and this supports the results of biochemical analysis.

On the other hand, sections of kidney of rats from groups $(\mathrm{E} \& \mathrm{~F})$ taken MO extracts with different doses after cisplatin administration showing that there was no improvement in the damadge nduced by cisplatin (Fig. $1 \mathrm{E} \& \mathrm{~F}$ ). 


\section{Safaa M. Faid}
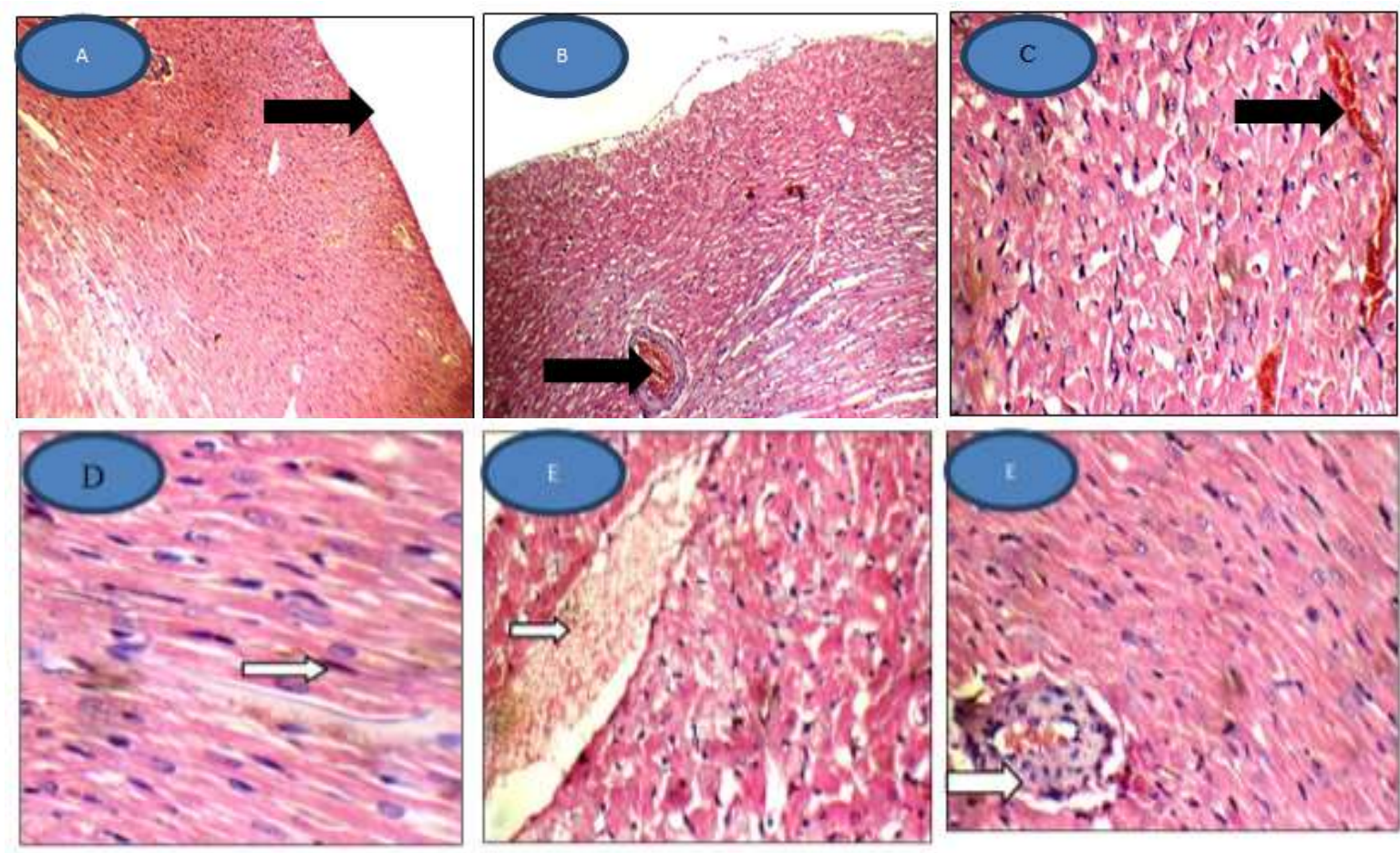

Fig. 1-A: Group A (-ve Control), longitudinal section of cardiac muscles of rat showing the normal structure of cardiac muscles with cardiac wall showing normal pericardium (arrow), viable cardiac muscle fibers, and normal myocardial blood vessels (X 200).

Fig 1-B: Group B (Positive control), longitudinal section of cardiac muscles of rat showing the structure of cardiac muscles with cardiac wall showing detached pericardium, viable cardiac muscle fibers, and mildly congested myocardial blood vessels (arrow) (X200)

Fig 1-C: Group c; $M O(L D)+C I S)$ : transverse section of cardiac muscles of rat showing viable cardiac muscle fibers with distinct cell borders and central ovallelongated nuclei, and average myocardial blood vessel (arrow) (H\&E X 400).

Fig 1-D: (Group d; $\mathrm{MO}(\mathrm{HD})+\mathrm{CIS}$ ): longitudinal section of cardiac muscles of rats showing viable cardiac muscle fibers with distinct cell borders and central ovallelongated nuclei, Fibroblast nuclei tend to be more flattened and darker staining than those of cardiac muscle cells and were peripherally located (arrow) and average myocardial blood vessel (H\&EX 400).

Fig 1-E: (Group e; CIS+MO (LD), transverse section of cardiac muscles of rat showing viable cardiac muscle fibers with indistinct cell borders, intra-cytoplasmic vacuoles, and mildly congested myocardial blood vessel (arrow) (H\&E X 400)

Fig 1-F: (CIS+MO (HD), longitudinal section of cardiac muscles of rat showing viable cardiac muscle fibers with distinct cell borders and central ovallelongated nuclei, and mildly congested myocardial blood vessels (arrow) (H\&E X 400).

\section{2- Lung Tissue:}

It was obvious from Figure (2A) the normal histological structure of lung in rats of the negative control group with normal alveolar spaces. However, extensive alveolar oedema and severe alveolar damage extensive with alveolar septal fibrosis, infiltration of polymorphic nuclear leucocytes, and haemorrhagic foci were observed in the lungs of CIS group (B) as shown in Figure (1B).

There was an improvement in the pleural mesothelium, pulmonary arterioles, structure of the bronchioles, and alveolar structure by the usage of (MO) extract before CIS administration (Fig $1 \mathrm{C} \& \mathrm{D}$ ). This may be due to the protective effect of phyto - antioxidants components 


\section{Potential protective role of Melilotus officinalis extract against Cisplatin -induced cardiac and pulmonary toxicities in rats}

particularly flavonoids in of the MO extract on the lungs and this supports the results of biochemical analysis. Examinations of sections of lungs rats from groups $(\mathrm{E} \& \mathrm{~F})$ taken cisplatin followed by different doses of MO extracts showed that there was no improvement in the damadge induced by cisplatin (Fig. $2 \mathrm{E}$ $\&$ F). Tissue damage may be linked to a decline in antioxidant defence mechanisms in the pathogenesis of cisplatin-induced oxidative damage (Pratibha et al.,2006).

The present histopathological manifestations of oxidative damage in lung tissue caused by cisplatin were not observed in the blood and lung tissues of the the negative control group and in groups of rats that used MO extract before using cisplatin. These findings indicate that MO extract may be clinically effective against cisplatin-associated lung toxicity.
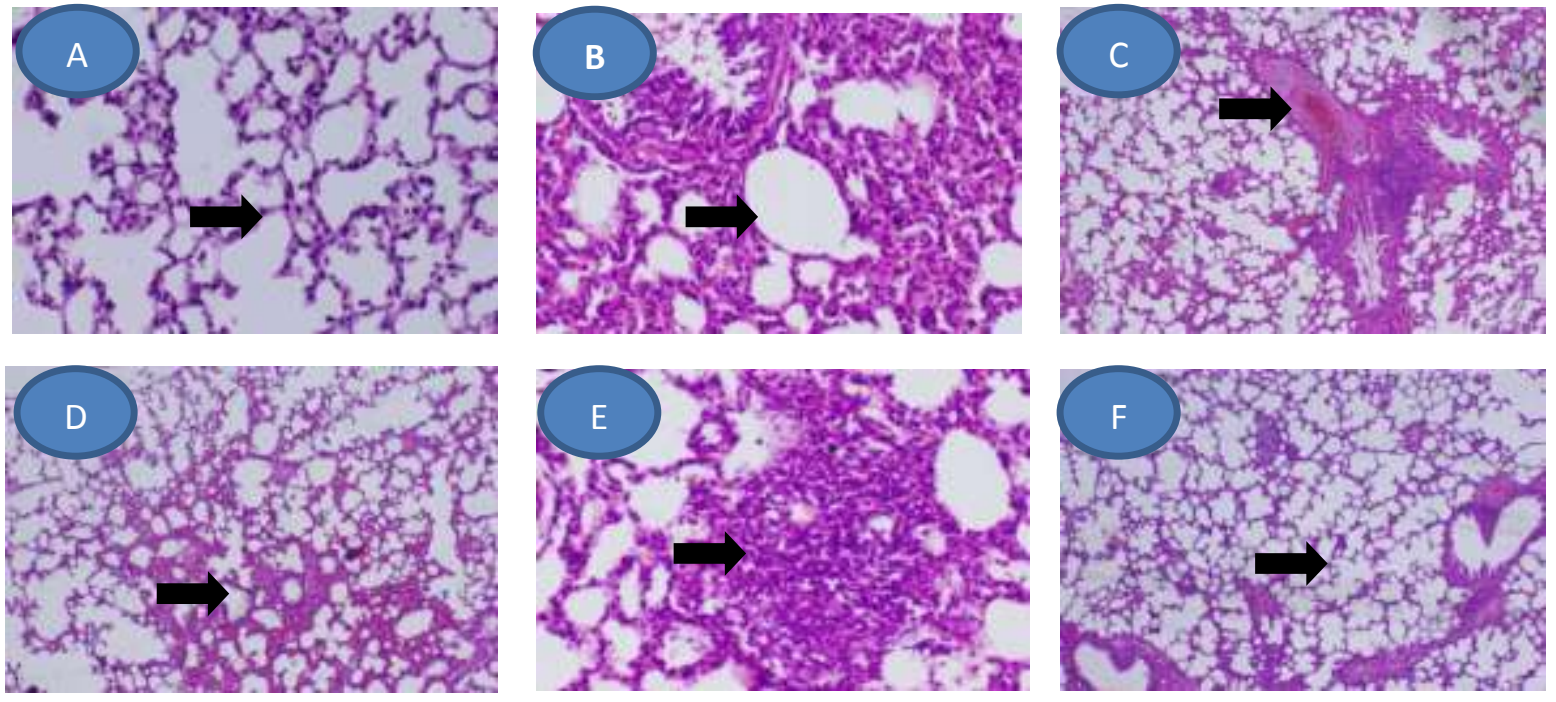

Fig. 2. Sections of lung of different investigated groups of rats, stained with HX-E.

Fig. 2- A: Group A (-ve Control), section of lung of rat showing normal alveolar structure (arrow) (X 200.

Fig. 2-B: Group B (Positive control), section of lung of rat showing sloughing of the bronchiolar epithelium with thickening in the interalveolar wall (arrow) (X 200).

Fig. 2-C: Group C (MO(LD)+CIS), section of lung of rat showing congested peri-bronchiolar blood capillaries (arrow)and peribronchiolar mononuclear cells aggregation (X 200).

Fig. 2-D: Group D (MO(HD)+CIS), section of lung of rat showing slight congested peri-alveolar blood capillaries (X 200).

Fig. 2-E: Group E (CIS + MO(HD), section of lung of rat showing focal aggregation of mononuclear inflammatory cells (arrow) (X 400).

Fig. 2-F: Group F (ClS+MO (HD), section of lung of rat showing wide areas of apparently normal lung parenchyma with focal areas of interstitial pneumonia (arrow) (X 200).

\section{Conclusion}

In conclusion, the present study substantiates that pulmonary and cardiac toxicity induced by $\mathrm{Cis}$ is associated with enhanced oxidative stress. To avoid the side effects of chemotherapeutic medication treatment by cisplatin, MO extract as a possible antioxidant could be used before the treatment. The findings strengthen MO's defence mechanism against Cis-induced oxidative stress and support its therapeutic usage in pulmonary and heart damage.

\section{REFERENCES}

Adejuwon, S.A.; Femi-Akinlosotu, O.M. and Omirinde, J.O. (2015). Cisplatin-induced testicular dysfunction and its amelioration by 


\section{Safaa M. Faid}

Launaea taraxacifolia leaf extract. Andrologia, 47: 553-559.

Afsar, T.; Razak, S.; Almajwal, A. and Khan, M.R. (2018). Acacia hydaspica R. Parker ameliorates cisplatin induced oxidative stress, DNA damage and morphological alterations in rat pulmonary tissue. BMC Complementary and Alternative Med., 18:49.

Ali, B.H. and Al Moundhri, M.S. (2006). Agents ameliorating or augmenting the nephrotoxicity of cisplatin and other platinum compounds: a review of some recent research. Food Chem. Toxicol.; 44:1173-83.

Al-Snafi, A.E. (2020). Chemical constituents and pharmacological effects of Melilotus officinalis- A Review. IOSR Phr.,10(1): 26-36

Anwar, M.S; Mohtasheem, M.; Azhar, I.; Ahmed, S.W.; Bano, H. (2008). Chemical constituents from Melilotus officinalis. J. Basic Appl. Sci.,4:89-94.

Anwer, M.S.; Shamim, S.; Ahmed, S. and Mohtasheem, M. and Azhar, I. (2015). Hypotensive activity of Melilotus officinalis (L.) Pallas. Eur. J. Med., 3:80-5

A.O.A.C. (2005). Official Method of Analysis. Association of Official Analytical Chemists Washington DC, USA.

Ayala, A.; Munoz, M.F.; Argüelles, S. (2014). Lipid peroxidation: production, metabolism, and signaling mechanisms of malondialdehyde and 4-hydroxy-2nonenal. Oxid. Med. Cell Longev., 2014: 360438.

Braga, P.C.; Sasso, M.D.; Lattuada, N.; Marabinil, L.; Calo, R.; Antonacci, R., et al. (2013). Antioxidant activity of Melilotus officinalis extract investigated by means of the radical scavenging activity, the chemiluminescence of human neutrophil bursts and lipoperoxidation assay. J. Med, Plant Res.,7:358-65.

Chapman, D.G.; Jastilla, R. and Campbell, J. A (1959): Evalution of protein efficiency ratio. Can. J. Biochem. Physiol., 37:674-686.

Chen, Y.; Jungsuwadee, P.; Vore, M.; Butterfield, D.A. and St Clair, D.K. (2007). Collateral damage in cancer chemotherapy: oxidative stress in nontargeted tissues. Mol. Interventions, 7:147-156.

Chowdhury, S.; Sinha, K.; Banerjee, S.; Sil, P. (2016). Taurine protects cisplatin induced cardiotoxicity by modulating inflammatory and endoplasmic reticulum stress responses. BioFactors, 42.

Dugbartey, G.J.; Peppone, L.J. and de Graaf, I.A.M. (2016). An integrative view of cisplatininduced renal and cardiac toxicities: molecular mechanisms, current treatment challenges and potential protective measures. Toxicol., 371:58-66. doi:10.1016/ j.tox.2016.10.001.

Eken, M.; Ersoy, G.; Kaygusuz, E.; et al. (2019). Etanercept protects ovarian reserve against ischemia/ reperfusion injury in a rat model. Arch. Med. Sci.,15: 1104-12.

El-Awady, E.; Moustafa, Y.M.; AboElmatty, D.M. and Radwan, A. (2011). Cisplatin - induced cardiotoxicity: mechanisms and cardioprotective strategies. Eur. J. Pharmacol., 650:335-41.

El-Motelp, B.A.A.; Ebrahim, M.T.; Mohamed, H.K. (2021). Salvia officinalis extract suppresses the changes in bone metabolism associated with osteoporosis in ovariectomized rats. Pak. J. Biol. Sci., 24:434-444.

El-Sawalhi, M.M and Ahmed, L.A (2013). Exploring the protective role of apocynin, a specific NADPH oxidase inhibitor, in cisplatin- 


\section{Potential protective role of Melilotus officinalis extract against Cisplatin -induced cardiac and pulmonary toxicities in rats}

induced cardiotoxicity in rats. Chemico-biological Interactions, 207.

Geyikoglu, F.; Isikgoz, H.; Onalan, H., et al. (2017). Impact of high-dose oleuropein on cisplatin-induced oxidative stress, genotoxicity and pathological changes in rat stomach and lung. J. Asian Natural Products Res., 19: 1214-1231.

Hassen, M.T.; Mohamed, H.K.; Montaser, M.M.; El-Sharnouby, M.E.; Awad, N.; Ebiya, R.A. (2021). Molecular, immunomodulatory, and histopathological role of mesenchymal stem cells and beetroot extracton cisplatin induced testicular damage in albino rats. Animals , 11: 1142.

Heidari, M.R.; Najafi, F.; Asadi, P.A.; Ansari, M.; Zahedi, M.J. and Vahedian, M. (2001). Analgesic and ulcerogenic effect of methanolic extract of Melilotus officinalis. J. Kerman Univ. Med. Sci., 8:210-68

Jiang, W.; Jin, P. and Wei, W. (2020). Apoptosis in cerebrospinal fluid as outcome predictors in severe traumatic brain injury: An observational study. Medicine (Baltimore) 99:e20922.

Khosroyar, S. and Arastehnodeh, A. (2018). Comparison of antiinflammatory and antioxidant capacity of alcoholic extraction of Fraxinus fxcelsior and Melitotus officinalis plant. Plant Archives, 18: 443-448.

Kisaoglu, A.; Borekci, B.; Yapca, O.E.; Bilen, H. and Suleyman, H. (2013). Tissue damage and oxidant/antioxidant balance. Eurasian J. Med., 45: 47-49.

Leo, F.; Pelosi, G.; Sonzogni, A.; Chilosi, M.; Bonomo, G. and Spaggiari, L. (2010). Structural lung damage after chemotherapy: fact or fiction?," Lung Cancer, 67: 306310.

McRae, N.L.; Howlett, K.F.; McNeill, B.; McCulloch, D.R. and Stupka, N.
(2020). Genetic reduction of the extracellular matrix protein versican attenuates inflammatory cell infiltration and improves contractile function in dystrophic mdx diaphragm muscles. Sci. Rep., 10:11080.

Nakhaee, A.; Bokaeian, M.; Noori, S. and Mahboob, T. (2010). Antioxidant effect of carnosine pretreatment on cisplatin-induced renal oxidative stress in rats. Ind. J. Clin. Biochem., 25:86-91.

Nasser, N.M.; Al-Araji, M. and Widad, M.K. (2014). Antifungal activity of Mellilotus officinalis of Iraq. J. Chem. Pharm. Res.,6:611-7.

Nita, M.; Grzybowski, A. (2016) The Role of the Reactive Oxygen Species and oxidative stress in the pathomechanism of the age- related ocular diseases and other pathologies of the anterior and posterior eye segments in adults. Oxid. Med. Cell. Longev., vol. 2016: 1-23.At: http://dx.doi.org/ 10.1155/2016/3164734

Ohkawa, H.; Ohishi, N.; Yagi, K. (1977). Assay for lipid peroxides in animal tissues by thiobarbituric acid reaction. Anal Biochem., 95:351351.

Pandurangan, M.; Veerappan, M. and Kim, D.H. (2015). Cytotoxicity of zinc oxide nanoparticles on antioxidant enzyme activities and mRNA expression in the cocultured C2C12 and 3T3-L1 cells. Appl. Biochem. Biotechnol., 175:12701280.

Paun, G.; Neagu, E.; Albu, C.; Savin, S. and Radu, G.L. (2020). In Vitro evaluation of antidiabetic and anti inflammatory activities of polyphenolic-rich extracts from Anchusa officinalis and Melilotus officinalis. ACS Omega, 5: 13014-13022.

Plesca-Manea, L.; Pârvu, A.E.; Pârvu, M.; Taamas, M.; Buia, R. and Puia, M. 


\section{Safaa M. Faid}

(2002). Effects of Melilotus officinalis on acute inflammation. Phytother Res.,16:316-9.

Pratibha, R.; Sameer, R.; Rataboli, P.V.; Bhiwgade, D. A. and Dhume, C.Y. (2006). "Enzymatic studies of cisplatin induced oxidative stress in hepatic tissue of rats. Eur. J. Pharmacol., 532: 290-293.

Rosic ,G.; Selakovic, D.; Joksimovic, J. et al. (2016). The effects of $\mathrm{N}$ acetylcysteine on cisplatin-induced changes of cardiodynamic parameters within coronary autoregulation range in isolated rat hearts., Toxicol. Letters 242:34-46.

Taylor, P.C. (2001). Anti-TNF therapy for rheumatoid arthritis and other inflammatory diseases. Mol. Biotechanol.,19(2):153-168.
Topal, İ.; Bilgin, A.Ö.; Çimen, F.K.; Kurt N.; Süleyman, Z.; Bilgin, Y.; Özçiçek, A. and Altuner, D . (2018). The effect of rutin on cisplatin-induced oxidative cardiac damage in rats. Anatol. J. Cardiol., 20: $136-42$.

Unver, E.; Mustafa, T.; Olmez, H.; Kuzucu, M.; Cimen, F.K. and Zeynep, S. (2019). The Effect of taxifolin on cisplatin-induced pulmonarydamage in rats: A Biochemical and Histopathological Evaluation, 17: 1-6.

Woo, M.; Hakem, R.; Soengas, M.S.; Duncan, G.S.; Shahinian, A.; Kägi, D.; Hakem, A.; McCurrach, M.; Khoo, W.; Kaufman, S.A.; et al. (1998). Essential contribution of caspase 3/CPP32 to apoptosis and its associated nuclear changes. Genes Dev., 12: 806-819.

الدور الوقائي المحتمل لأكاليل الملك (الحندقوق) ضد السمية القلبية والرئوية الناتجة عن سيسبلاتين في فئران التجارب

$$
\begin{aligned}
& \text { صفاء مصطقى عبد الفتاح فايد } \\
& \text { قسم الاقتصاد المنزلي ـ كلية التربية النوعية ـ جامعة عين شمس ـ القاهرة ـ مصر }
\end{aligned}
$$

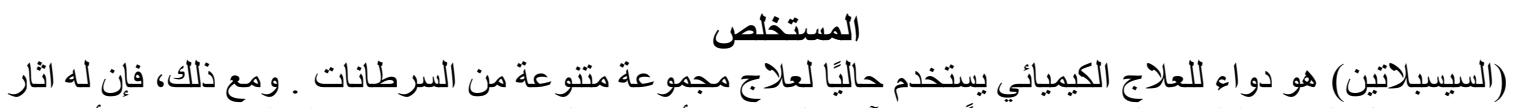

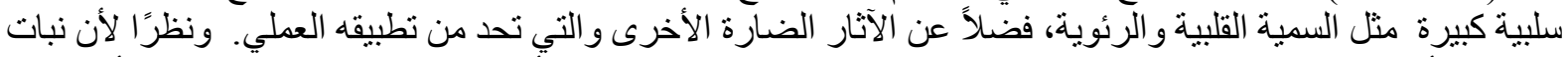

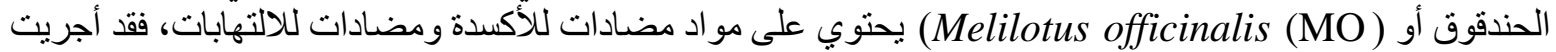

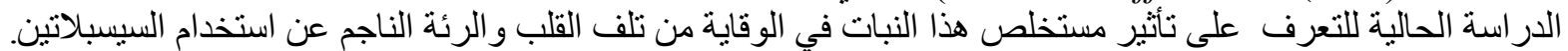

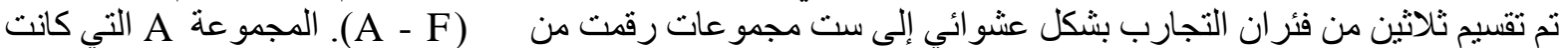

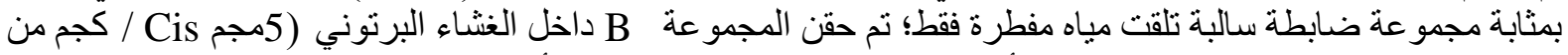

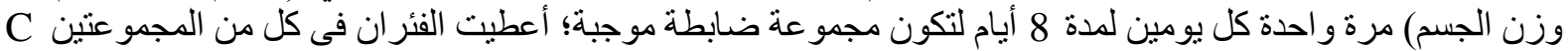

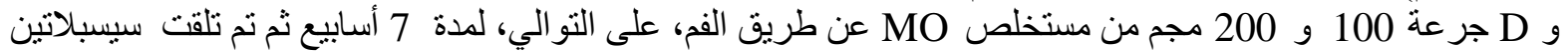

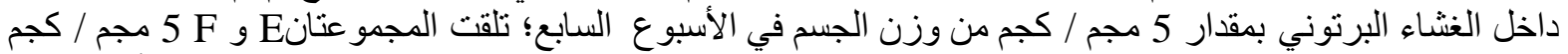

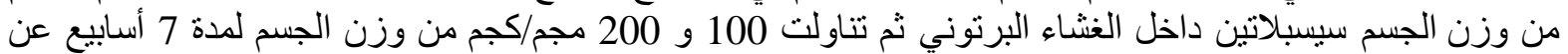

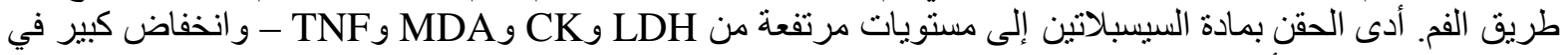

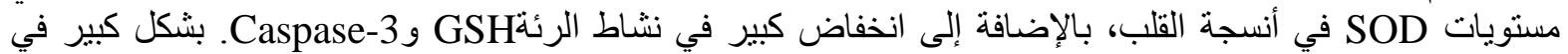

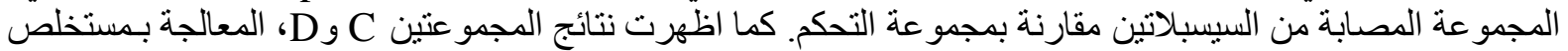

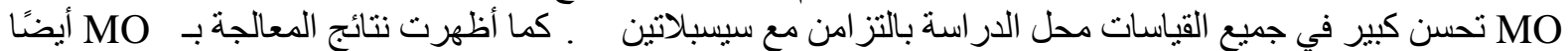

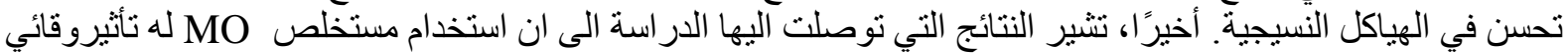

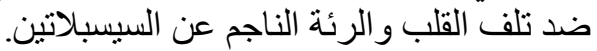

